\title{
INDUSTRIAL STRUCTURE AND SPATIAL INPUTS AND OUTPUTS IN THE AMERICAN ECONOMY: COMMEN T
}

John M. Brazzel

Office of Economic Opportunity

The primary statistical finding of this pape $r$ is that increased forward linkage in U.S. manufacturing leads to increased spatial concentration of forward-and backward-linkage industries. Several conclusions and recommendations in the paper are based on this finding.

\section{EFFECTS OF THE TRANSPORT SECTOR ON INDUSTRY LOCATION}

Increased industrial linkages in the U. S. are surmised in the paper to have resulted in increased spatial concentration because of transport inputs. Thus the author argues that while transport cost have beenfalling overtime, the conclusion of other authors that the role of the transport sector has declined as a location factor in not necessarily correct.

No conclusion is possible about the transport sector based on the data and statistical results contained in the paper. Data for one point in time that included interindustry sales and purchases and average shipment distances of industry inputs and outputs are used. Data describing transport costs and industry structure over time are needed.

The statistical results do not consider the possible influence on spatial concentration of: 1) agglomeration economies among industries or among firms within industries, 2) the location of final demand markets, or 3) the location of factor markets. These may well be more important than industrial markets in explaining both spatial concentration in U.S. manufacturing and the role of the transport sector.

\section{INVESTMENT AND DEVELOPMENT POLICY FOR UNDERDEVELOPED COUNTIES AND DOMESTIC REGIONS}

The author recommends for domestic regions and for underdeveloped countries an emphasis on attracting manufacturing with high forward and backward linkages because both types of linkages lead to turn to increased spatial concentration. This recommendation may or may not be valid; it is not supported by the data used or the empirical findings.

U. S. data are not very helpful for analyzing domestic regions and underdeveloped countries, particularly because of differences in the amount and composition of imports and exports in final demand and industrial markets. Even if the data were assumed appropriate, empirical support is given in the paper for the beneficial effect of forward linkages but not backward linkages.

\section{INVESTMENT CRITERION FOR REGIONAL ECONOMIC DEVELOPMENT}

An investment criterion is suggested in the paper to implement the conclusions about regional economic development. The goal implicit to the criterion is scary - attract as much manufacturing to the region as possible. No consideration is given here or anywhere in the paper to the possible consequences of such a policy, that is, the consequences for the distribution of employment and income, for living conditions, for the environment. 


\section{FOOTNOTES}

${ }^{1}$ Charles Richter, "The Impact of Industrial Linkages on Geographic Association, "Journal of Regional Science, Vol. 9, ( ), pp.

2 David Simpson and Jinkichi Tsukui, "The Fundamental Structure of Input-Output Tables, An International Comparison, "The Review of Economics and Statistics, XLVII (November 1965), pp. 438-440.

${ }^{3}$ I- 0 type multipliers would not be particularly relevant here as it would be hard to explain why a particular value of a national I-0 multiplier could contribute in one way to spacial concentration within the region; however, a high regional multiplier value might well depend upon whether or not the industry was a member of a spacial industrial complex. There is a relationship at the national level between the measure of backward linkage and the Type II multiplier. Using updated 1967 data we have $\mathrm{iY}=0.370+10.698 \mathrm{X}$ and $\mathbf{r}=.501$; the Type II multiplier is, $\mathrm{Y}$, and backward linkage is represented by, X, For a discussion of the 1967 I-0 table upon which this sample regression is based see: Robert H. Elrod and Reston E. LaFerney, Sector Income and Employment Multipliers: Their Interactions on the National Economy, Technical Bulletin No. 1421, Economic Research Service, U.S. Department of Agriculture.

${ }^{4}$ Hollis B. Chenery and Tsunehike Watanake, "International Comparisons of the Structure of Production, "Econometrica Vol. 26 (October 1958), pp. 494-496.

${ }^{5}$ Op. Cit. , David Simpson and Jinkichi Tsukui, p. 437. For a concise statement of the more general meaning in Economics of a triangular structure see: K. C. Kogiky, An Introduction to Macroeconomic Models, (New York, McGraw-Hill Book Company, 1968), pp. 18-31.

${ }^{6}$ Alfred Weber, Theory of the Location of Industries, (Chicago; University of Chicago Press, 1929), pp. 17-36.

${ }^{7}$ For a recent statement of this position see: Allan Pred, "The Concentration of High-Value-Added Manufacturing, "Economic Geography, Vol. 41, No. 2, 1965, pp. 108-132.

${ }^{8}$ For a general discussion of the importance of "transportation orientation" see: Gerald J. Karaska and David F. Bramhall, Locational Analysis For Manufacturing, (Cambridge: The MIT Press, 1969), pp. 65-107.

${ }^{9}$ Albert O. Hirschman, The Strategy of Economic Development, (New Haven: Yale University Press, 1958), pp. 116-117.

${ }^{10}$ Benjamin Higgins, Economic Development, Revised Edition (New York: W. W. Norton \& Company, 1968), pp. 400-404. 